\title{
Persisting Patterns-Graduate Degrees and Gender Ratio in Sweden 1960-1990
}

\author{
Hanna Markusson Winkvist \\ Department of Historical Studies, University of Gothenburg, Sweden \\ Email: hanna.winkvist@history.gu.se
}

Received 15 April 2016; accepted 18 July 2016; published 22 July 2016

Copyright (C) 2016 by author and Scientific Research Publishing Inc.

This work is licensed under the Creative Commons Attribution International License (CC BY). http://creativecommons.org/licenses/by/4.0/

(c) (i) Open Access

\section{Abstract}

This article addresses the ratio of women in Swedish academia on the graduate level, in particular the distribution of Ph.D. degrees among disciplines during the era of expansion in higher education. In the decades succeeding World War II, the Swedish educational system underwent pervasive changes, which among other things, were aimed at channeling a larger part of the population into higher education. This was a matter of national interest, as increased success in undergraduate studies would enhance the general level of competence and help promote Sweden as part of the cutting edge in research. In order to assess findings in previous research, this study examines the distribution in fields, field size, and periods of substantial growth in Ph.D. degrees, and their correlationswith changed gender ratios. Trends regarding women with Ph.D.s on an aggregated level show a gradual increase beginning in conjunction with the massive growth from 1969 to 1974. This expansion does not entail a boom in the ratio of women, albeit women increased exponentially over these years; during the 1960s women were still scarce. The gradual and steady increase is evident throughout the whole period, but the gender gap remains wide on an aggregated level; in 1990, one in four Ph.D. graduates was a woman. Examining this picture by field provides a more elaborate view. The crucial question is: If size matters, do crowded fields reveal greater gender imbalance than less crowded ones? After the upturn in the early 1970s, the relative gender gap in these disciplinary domains cannot exclusively be described as a successively, yet slowly, diminishing gap. The narrative of a linear process over time resulting in enhanced gender balance on the graduate level should be modified to reflect that trends indicate a fluctuating pattern where the low ratio of women is persistent rather than progressive.

\section{Keywords}

Graduate Studies, Gender Balance, Higher Education, Swedish Academia 


\section{Introduction}

Sweden is in many respects perceived to be a country with high gender equality with its extensive parental insurance system, child benefits, and public child care program. These components of the welfare state seem to contribute to a strong labor market performance. In 2012, Sweden reached an employment rate of close to 80 percent for the age group of 20 - 64 (Žáková, 2013) ${ }^{1}$. Nevertheless, regarded as one of the most progressive countries in the world, the gender ratio gap is still a persistent problem. In this respect, income distribution and part-time employment as well as sick leave show distinct gendered patterns, i.e. women earn less relative to men; they are over-represented in the part-time jobs category (which in turn negatively affects their retirement benefits); and suffer from health problems (measured by their share of sick leave) to a greater extent than men (Arbetsmiljöverket, 2013; Öberg \& Öberg, 2013; Johansson \& Katz, 2007). Moreover, Sweden has the most gender-segregated labor market in Europe; i.e. there is a division between domains of work where men and women are occupied in separate spheres (Arbetsmiljöverket, 2013). Although the gender-ratio gap is lesser among the better educated, Swedish academia is no exception to the above. In several reports over the past decades, this fact has been both highlighted and problematized by scholars as well as politicians and policy makers. However, although historical circumstances are mentioned or even highlighted, the chronological perspectives are often too short, contrary to the fact that an appropriate understanding of contemporary conditions requires a deeper analysis of the past.

In order to explore the aggregated mechanisms behind the gender ratio gap in academia, it is necessary to first both compile and historicize contemporary official data. In this study, therefore, such data will be collected and analyzed over three decades, starting in the early 1960s when higher education in Sweden (as in the rest of the world) transformed from an elitist and highly exclusive institution into an activity accessible to the masses. In other words, the student went from being "one of a kind" to "kind of anyone" (Persson, 1998). This structural change also affected the gender balance; the women's share, as students and as graduate students, increased (albeit modestly in the latter case). Whether this shift correlates with an enhanced gender balance or not is yet to be investigated, but the main finding in a system-oriented, macro-leveled study of the expansive 1990s shows that growth does not automatically generate increased horizontal gender balance among Ph.D. students and graduates (Silander, 2010).

The aim of this article is to further explore how the expansion in higher education affected the proportion of women in Ph.D. programs. The chronological scope of the survey stretches over three decades, 1960-1990, and of special interest is the distribution among fields of research. In the following section, motives, point of departure, aim, and data and method are described and elaborated.

\subsection{Background}

In the post war era, higher education and research underwent pervasive changes in Sweden as in the rest of the world (Schofer \& Meyer, 2005). In order to reassure a sustainable and competitive development of the welfare state, Swedish politicians were highly influenced by American state-governed investments in this domain (Andrén, 2013; Berggren, 2010). During the 1950s, several state-governed investigations were launched, and throughout the following decade, these efforts were intensified. Embarking on an academic course in life was no longer to be seen as an opportunity only for the societal elite, but instead as available for everyone with intellectual talent, not least since Swedish policymakers feared that there were untapped masses of scholarly and scientific capacity (Markusson Winkvist, 2014). As represented by democratic values, the idea of widening the participation in higher education for the nation's good represented an ideological shift in education policy —and practice.

From the mid-1940s to the mid-1960s, the total number of students in the country more than doubled from about 14,000 to nearly 40,000 , and during the next 20 years, it rose to 150,000 . The ratio of female students increased from just over 35 percent in the mid-1960s to barely 60 percent three decades later (Statistical Yearbook of Sweden, 1945-1981). This increase occurred in relation to an "academization", i.e. incorporation into the academic organizational system, of traditionally female-dominated (and oriented) programs, such as teacher training and health-care education in 1977 (Högskoleverket, 2006). Parallel to this, an expansion in graduate studies also followed. The proportion of female Ph.D.'s increased as well—but through the 1960s the amount

\footnotetext{
${ }^{1}$ To note: figures hide facts about high levels of un-employment among young people without upper-secondary education, non-EU migrants,
} and unskilled. 
never exceeded ten percent (see Figure 2). A few years in to the 1970s, the ratio grew by approximately four percentage points, and at the end of the decade, women represented just 20 percent (see Figure 2). It goes without saying that these figures do not reflect the progress at the undergraduate level, even when time-lag effects are accounted for.

In 2010, women faculty in Swedish academia represented 36.7 per cent of the total (Grove, 2013). However, distribution varied between fields of research (European Commission, 2013). This imbalance is both well known and consistent with the general pattern in Europe, which reveals that there are more women in the humanities, and fewer within engineering and technology (European Commission, 2013). In earlier research, this imbalance is sometimes described in terms of women's clustering in "soft" fields as opposed to men in "hard"; a description which, in itself, reproduces gender stereotypes (Addis, 2010) ${ }^{2}$. Regardless of this remark, academia is considered to be male-dominated, imprinted by its long homosocial history, which in turn permeates academic culture (Rosenbeck, 2014; Bourdieu, 2001). In spite of increasing numbers of female students, Ph.D.’s, and faculty members, women still encounter difficulties, such as discrimination, in their academic career (Silander, 2010; Husu \& de Cheveigné, 2010; Andersson, 2007; Husu, 2005). Historically, academic virtues and values are linked to a male subject; therefore, this connotation is interpreted as a preferred masculinity,a notion, which still seems to be ingrained in academic culture. As sociologist Carlo Barone has observed, the impact of this culture on women's career paths is conclusive and "gender segregation in higher education is highly resistant to change" (Barone, 2011: p. 158). As a consequence, women are at times regarded as lesser equipped, and are assessed according to their gender rather than their actual performance (Boring, Ottoni, \& Stark, 2016; Schiebinger, 1999).

Although academia is defined as a progressive, meritocratic, and unbiased system, both vertical (division between fields) and hierarchical (ranking between positions) gender segregation is more or less perpetuated (European Commission, 2015). However, on the Ph.D. graduate level (particularly in the EU, but not without exceptions), the gender ratio is gradually moving towards enhanced gender equality (European Commission, 2013). Academia has, ever since the post war era, "slowly but surely" progressed towards gender equality (Ramirez \& Wotipka, 2001). Nevertheless, there is little evidence that suggests that gender balance and/or inequality is a self-correcting process (Grove, 2013; European Commission, 2013).

In previous research, a number of different explanatory factors for hierarchical gender division can be identified. Some studies point to the impact of organizational factors, e.g. the logics of a specific organization repel women and/or contribute to disadvantages for women (Acker, 1990). Organizations are never gender neutral, rather all organizations develop inequality regimes over time (Acker, 2006). One effect of this is sometimes metaphorically described as an effect of a glass ceiling hindering the advancement of women. Other frequently used metaphors to describe the same effect are "sticky floors" and "leaky pipelines".

Another important explanation for gender imbalance in an international context is what can be described as the "human capital" factor. This addresses the work and family-life balance women (trying to engage) in academia have to manage (Mason, Wolfinger, \& Goulden, 2013). Other studies point out that women often lack or have less access to resources or social capital (in keeping with Pierre Bourdieu) such as the support of distinguished scientists and scholars, or at least, lack personal ties, and connections to influential networks (Sandström, Wold, \& Johansson, 2010). In peer-review and in grant application processes, women are-all other factors equal_accepted and/or awarded to a lesser extent (Melin, 2007; Wennerås \& Wold, 1997). In spite of meritocratic values, it seems as if “[b] iases are unavoidable” (Lamont, 2009: p. 243). Nevertheless, a number of statistical studies show that women seem to trickle out of the system—or, as often described, the pipeline-even when the above factors are corrected for (Chrapkowska, 2006; Billard, 1994; Astin \& Bayer, 1979). Of special interest to this study is the field size on the one hand, and substantial growth in Ph.D. degrees in general on the other, and their (possible) impact on gender ratio.

\subsection{Point of Departure}

The Ph.D. graduate distribution by research field reveals the same overall pattern as the distribution of researchers in general. On average in EU-27 (the number of EU countries up until 2013), female Ph.D.’s are dominant in the fields of education (64 percent), health and welfare (56 percent), and humanities (54 percent); whereas

\footnotetext{
${ }^{2}$ The method to epistemologically sort and categorize different fields of science/research originates with Auguste Comtes in his attempt to stage a "hierarchy of the sciences". Along with the increased presence of women in research the notion of what should be considered as hard and soft has also changed.
} 
science, mathematics, computing, and especially engineering, manufacturing, and construction (26 percent women) are male dominated (European Commission, 2013). Interestingly enough, gender imbalances are greatest in those fields with the largest numbers of Ph.D. graduates, i.e. the more crowded, the larger the disproportion (European Commission, 2013). Within the field of education, 64 percent of graduates are women; yet, this

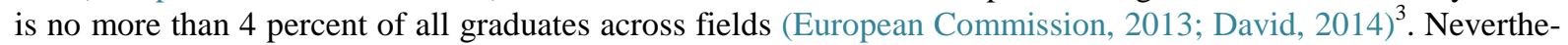
less, the variations between countries are significant, but Swedish proportions coincide with the general gender ratio pattern within the various fields (Table 1 ).

As Table 1 illustrates, the present-day gender ratio by field in Sweden is gender equal in four out of seven fields, at least in regard to policymaking standards, which allows a ratio flux between 40 and 60 percent. In the fields of education and engineering, the ratios stand out, but are not significant. The general understanding of male-dominated fields demonstrates a slow, yet reliable, change towards greater gender balance. It is important to note that the change has been interrupted and is not entirely represented by a positive rising graph. The proportion of female researchers in Sweden from 2002-2009 declined by 5.1 percent annually within the field of engineering and technology and by 1.0 percent annually in science-in total 9 percentage points (European Commission, 2013). On the one hand, this could be considered a setback and, maybe unsurprisingly, due to the mechanics of these (male) fields in particular. On the other hand, this might well be an occurring fluctuation in all fields at critical stages. An analysis of the occurrence of crowding over time would clarify this picture.

However, studies on the enrollment of college majors in eight European countries point to a generalized stagnation over the past few decades (Barone, 2011). ${ }^{4}$ Hence, the narrative of a constant, positive movement needs elaboration and revision. Findings on student enrollment by field (three cohorts: 1972, 1982, and 1992) over the same time period depict a considerable growth in numbers within the science and engineering sectors, especially for women whose numbers were almost tripled (Ramirez \& Wotipka, 2001). Female students also increased their share from 16.21 percent to 22.62 percent of the total, although this was a modest increase relative to other fields (Ramirez \& Wotipka, 2001). Based on these figures, women seem to benefit from less-restricted systems, e.g. the larger numbers of men entering science and technology and higher representation of women in non-science and non-engineering have a significant positive spill-over effect on women's enrollment in the traditionally male, yet historically new, fields (Ramirez \& Wotipka, 2001). Furthermore, results also suggest "the expanded participation of women in higher education empowers women to enter an expanded number of fields of study, rather than channels [sic!] them into fields that already have a large number of female students” (Ramirez \& Wotipka, 2001: p. 242). Nevertheless, inertia still characterizes the gender gap closing process of these fields.

The outline above refers to two studies that focus on diverse occurrences in order to identify the aggregated mechanism for achieving a decreased gender gap within scientific fields. One study points out the number of Ph.D.s per field relative to all fields, i.e. crowding, as crucial. The other suggests that the magnitude of enrollment, i.e. spill-over, affects distribution within fields. Despite empirical discrepancies between the semacro-level surveys, both mechanisms will be assessed on a Swedish data set, which comprises all disciplinary fields over a thirty-year time span. Hence, the purpose of this examination is to compile national data in order to analyze the impact of crowding and/or spill-over effects on the gender ratio of Ph.D. degrees in Swedish academia during the expansive era of 1960-1990. To what extent are these effects in play, and do they co-vary or are they the consequence of separate changes? Results are contextualized in relation to both patterns on undergraduate level and changes in policies/politics regarding higher education.

\section{Data and Method}

The chronology of the study has been set to cover the first period of expansion in the history of Swedish higher

Table 1. Proportion of female Ph.D. graduates by field in 2010, EU-27 and Sweden (\%).

\begin{tabular}{|c|c|c|c|c|c|c|c|}
\hline & Education & $\begin{array}{c}\text { Humanities } \\
\text { \& arts }\end{array}$ & $\begin{array}{l}\text { Social science, } \\
\text { business \& law }\end{array}$ & $\begin{array}{c}\text { Science, } \\
\text { mathematics } \\
\text { \& computing }\end{array}$ & $\begin{array}{l}\text { Engineering, } \\
\text { manufacturing } \\
\text { \& construction }\end{array}$ & $\begin{array}{l}\text { Agriculture } \\
\text { \& veterinary }\end{array}$ & $\begin{array}{c}\text { Health } \\
\text { \& welfare }\end{array}$ \\
\hline EU-27 & 64 & 54 & 49 & 40 & 26 & 52 & 56 \\
\hline Sweden & 71 & 54 & 53 & 41 & 31 & 56 & 63 \\
\hline
\end{tabular}

Source: European Commission, 2013: p. 54.

${ }^{3}$ The field of Education is today the most popular field with women-in 77 out of 84 countries-in the so-called Global North.

${ }^{4}$ The countries investigated are Spain, Italy, Austria, Germany, the Netherlands, the Czech Republic, Norway, and Finland. 
education. The analysis includes both the early tradition-bound universities of Uppsala and Lund and newer universities such as the ones in Stockholm, Gothenburg, Umeå, and Linköping 5 . As an effect of the expansion, institutions with degree-awarding powers at the doctoral level grew in number over time. Therefore, the study contains fewer universities in the beginning of its time period than in the end. However, the geographical distribution of these institutions will not be examined here.

The data set has been retrieved from two main sources. Records on Ph.D. degrees for the time period 1960 to 1972 are printed and organized by year in the Statistical Yearbook of Sweden. This material has been supplemented by additional primary reports from the administrative agency Statistics Sweden. Data from 1973 and onwards is available and searchable online in the agency's "Statistical database"6 . Records regarding the years 1962 and 1972 are partially missing, but their lack does not undermine the scope of this analysis ${ }^{7}$.

The quantity of Ph.D. degrees by field or “disciplinary domain”, which is the current term, serves as a starting point for the study. Data reports for the time period 1960-1972 were sorted according to degree and approximately based on the traditional division among faculties (Table 2(a)), while numbers from 1973 are categorized into twelve disciplinary domains as follows (Table 2(b)).

As illustrated in Table 2(a) and Table 2(b), the categories vary over time. For example, until 1972, degrees in theology were reported separately, but later were included as a part of the humanities since they accounted for a very limited share of the total. The same goes for degrees in economy, which have been included within the field of social sciences since 1973. Another example of merging disciplines is found in the agricultural and silvicultural degrees (and landscaping) that have been jointly accounted for since 1973. However, numbers are small, and these discrepancies will not have a decisive effect on the overall picture. Hence, the category "other" has also been left out. The following categorization has, therefore, been used in the assessments (Table 3).

In the next section of this article, the distribution between fields (ordisciplinary domains) regarding Ph.D. frequency is investigated. There is a discrepancy in terms of field division between this study and the referred EU-27 study, but this inconsistency is of minor importance since the impact of a crowding mechanism is in main focus rather than the logics within a certain field.

In the third section, in the assessment of spill-over effects, disciplinary domains or fields with a total of less than 40 Ph.D. graduates per year (as shown in Appendix C) are excluded. Thus, the investigation focuses primarily on the following five (5) fields: the humanities (including theology), medicine, science (including mathematics), social sciences, and technology.

\section{Students on the Graduate Level}

During the 1960s' “explosion” in educational admission, the number of first-year students quadrupled (Ekehammar \& Löfgren, 1981). Together with the political consensus at the time to endorse higher education investments, a significant growth in Ph.D. degrees also followed.

The positive development as shown in Figure 1 was, by and large, an effect of different reinforcements in graduate studies in the 1960s (Högskoleverket, 2006). Formal changes in both its structure and curricula favored efficiency, but it is important to note that the peak in 1974 can, at least partially, be described as artificial (Ekehammar \& Löfgren, 1981). In 1974, a reformed degree protocol came into force, and prior to this, a number of students enrolled in graduate studies within the former system were encouraged to finish within the new (and less complicated) curricula. Nevertheless, a slight decline followed (Högskoleverket, 2006). The general reduction was regarded as very troublesome "since research and development are considered to be of importance in a modern, industrialized society” (Ekehammar \& Löfgren, 1981: p. 2) ${ }^{8}$. As displayed in Figure 1, the decline for

\footnotetext{
${ }^{5}$ The universities in Uppsala and Lund were founded in 1477 and 1666 respectively. The private university colleges of Gothenburg and Stockholm were already established in the late 1800s, but did not receive university status until 1954 and 1960 respectively, when they also became state governed. In Northern Sweden, Umeå University was established in 1965, and ten years later, Linköping University was founded.

${ }^{6}$ In addition to this, detailed information on institutional level 1960-1972 is collected from the so-called Statistical reports/U; Link to database:

< http://www.scb.se/sv /Hitta-statistik/ >, 2015-03-12.

${ }^{7}$ In the official statistical data concerning 1972, only numbers from the fall semester have been compiled. In the case of the records for 1972 , gender is not taken into account. To fill these voids, it would be necessary to investigate each university archive.

${ }^{8}$ Original quote: “oroande bl.a. med tanke på den betydelse som forskning och utveckling anses ha i det moderna industrialiserade samhället.”
} 
Table 2. (a) Official categorization by field/disciplinary domain, 1960-1972; (b) Official categorization by field/disciplinary domain 1973-1990.

(a)
By field 1960-1972
Theology
Law

Medicine

Philosophy: Humanities

Philosophy: Social Sciences

Philosophy: Science

Technology

Economy

Odontology

Pharmaceutical

Veterinarian

Agricultural

Silvicultural

(b)

By disciplinary domain 1973-1990

Humanities and theology

Law

Medicine

Social sciences

Science

Mathematics

Technology

Odontology

Pharmaceutical

Veterinarian

Agricultural, silvicultural sciences, and landscaping

Other

Table 3. Disciplinary categories in survey.

$$
\begin{gathered}
\text { Disciplinary categories } \\
\text { Humanities and Theology } \\
\text { Law } \\
\text { Medicine } \\
\text { Social sciences and Economy }
\end{gathered}
$$

Science and Mathematics

Technology

Odontology

Pharmaceutical

Veterinarian

Agri-/silvicultural sciences, and landscaping. 


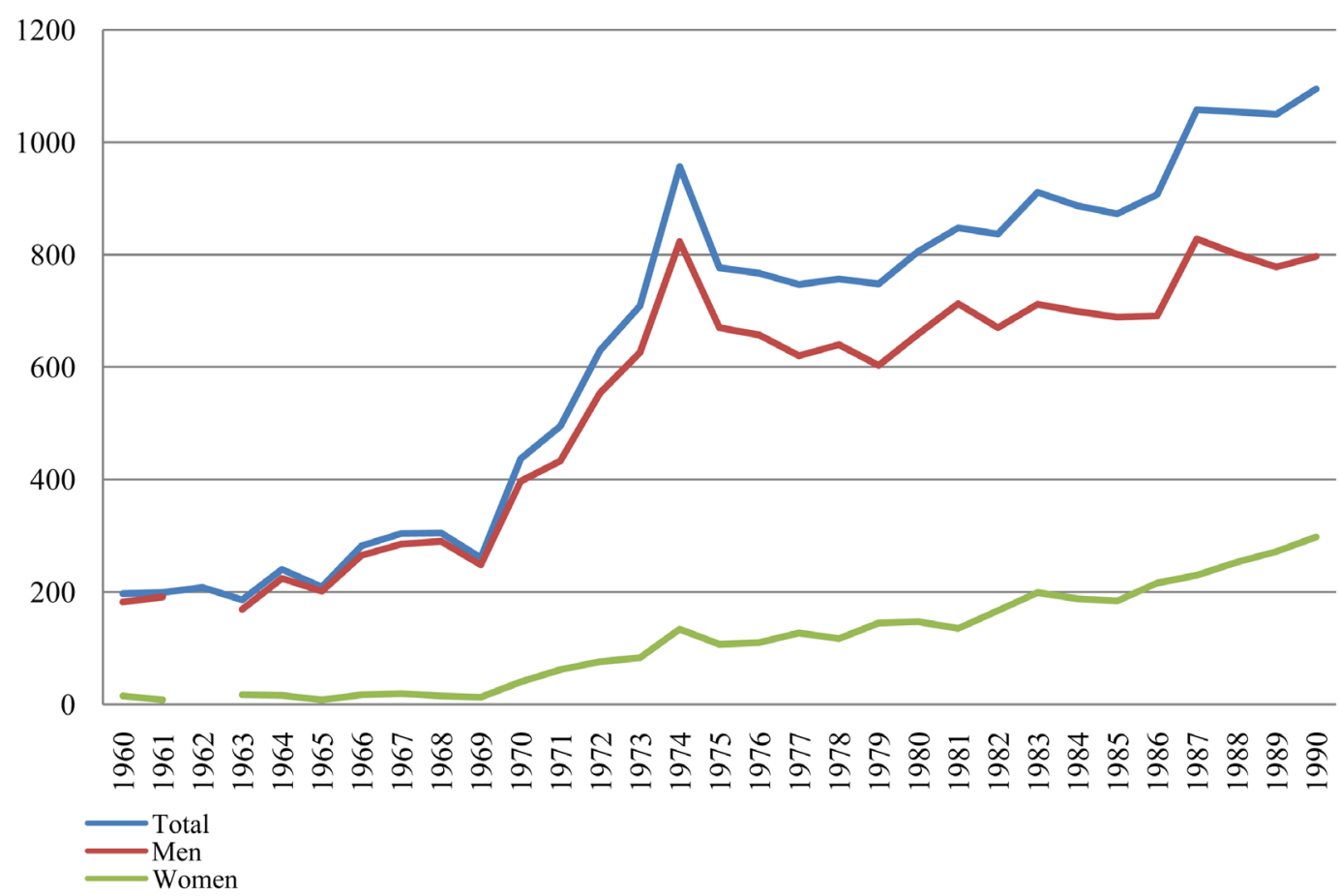

Figure 1. Ph.D. frequency, 1960-1990 (n). Sources: Statistical Yearbook of Sweden, 1960-1972; primary reports from the administrative agency Statistics Sweden (1960-1972); "Statistical database” (1973-1990), Statistics Sweden.

men was steeper than the one for women. Therefore, the increase in the number of women was at least partially affected by the decline in male Ph.D. graduates (Ekehammar \& Löfgren, 1981). A negative attitude towards research and its connotations has sometimes been suggested to explain this decrease, but studies indicate that research was not perceived as an unappealing endeavor (UHÄ, 1982). One decisive impediment, however, was the insecure financial situation of any potential graduate student. This had been pointed out in different contexts, but policy makers did not reach a general settlement until 1983 (Högskoleverket, 2006).

Changes in the educational system on the undergraduate and graduate levels are generated by changes in preceding educational levels. Swedish secondary schools transformed from a diverse structure-based on a conservative and also class-associated perception of schooling, in which children, depending on their social background were more or less predestined (and separated) into different tracks through the educational system —into a more cohesive education system during the 1960s, which in turn was a consequence of the reformed compulsory school in 1962 (Marklund, 1982). The underlying ideology promoting this shift valued widened accessibility in (higher) education as a manifestation of democratic progression and, therefore, was a hallmark of the welfare state. Nevertheless, the road towards the so-called "school peace" on the political level was a partially bumpy one (Marklund, 1982).

By the mid-1970s, almost one-third of all senior high-school graduates went into higher education (Marklund, 1982). A comparison with earlier periods might be incommensurable since the educational structure underwent a fundamental reformation, but it should be mentioned that a few decades earlier, one-third of all students originated from families with academic traditions, and these households counted for no more than one and a half of a vanishingly small percent of the total population (Husén \& Härnqvist, 2000). Parallel to this, the amount of senior high-school graduates from university preparatory programs decreased during the 1970s, whereas graduates from vocational programs remained consistent with the proportion from the previous decade (Ekehammar \& Löfgren, 1981). At the same time, female high-school graduates qualified for higher education were slightly overrepresented (Ekehammar \& Löfgren, 1981).

A survey by the Swedish psychologists Ekehammar and Löfgren (1981) show that, in the period 1962/19631978/1979, female undergraduate students, who counted for somewhat over 40 percent of all students, obtained degrees in proportion with their enrollment; i.e. the women's performance indicator was high. Thus, this is an important result especially since the belief at the time was that women were less motivated to finish their studies 
than were men. There is further evidence to contradict this view. Women's general attitudes towards research do not significantly differ from men's (Ekehammar, 1982). Moreover, less than one-fifth of students accepted into graduate studies were female (Ekehammar \& Löfgren, 1981). According to Ekehammar and Löfgren (1981), this ratio also approximately corresponds with the degree awarding frequency on a higher aggregated level. However, the data presented here does not confirm this picture. In the 1960s, women accounted for less than one in ten in graduate studies, but over time this slowly rises. At the end of the time period investigated, every fourth graduated Ph.D. student was a woman (Figure 2).

The issue of higher education and expansion is a multifaceted matter even though development over the decades in the post-war era is clear especially in terms of a slow-closing gender gap. However, this conclusion needs further review. To what extent is this image altered by an elaboration on the distribution among disciplinary domains? Put differently, there may be important differences between fields. The narrative might in fact contain several gender gaps, and if so, are they closing (at all)?

\section{Distribution among Disciplinary Domains}

The five quantitatively smallest disciplinary domains jointly comprise a share of 11.5 percent or less (per year) of the total. As shown in Diagram 2, a clear gap between these minor fields and the rest is also evident. Moreover, even if these domains (less diverse in terms of disciplines included) display an increase in numbers too, significant patterns cannot be identified (amplified graph in Appendix C).

During the 1960s and the 1980s, the field of medicine outscores all others in terms of total quantities (Figure 3). In the closing year of the investigated time period (1990), medicine counts for $375 \mathrm{Ph} . \mathrm{D} . \mathrm{s}$, which is almost as many as the fields of technology, social science, and the humanities together for that year: 377 Ph.D.s. During the 1970s (when all fields had increasing numbers of awarded Ph.D.-degrees), the field of science takes a leap and is on par with the Ph.D. frequency in medicine. The relatively new field of technology starts with very low numbers in the beginning of the 1960s and reaches a higher level than the humanities as well as social sciences during the 1980s.

But, entering the 1980s, an obvious pattern appears; the gap between medicine and science widens, while the frequency of Ph.D.'s in science and the cluster of other fields seems initially to have stagnated, i.e. the gap between them is consistently persistent. Regardless of the reason for these circumstances over time, in general, the gap(s) between fields remain. From where does this gap come? There is no single explanation for this; instead, there appear to be a number of elusive factors, which have more to do with culture and mentality, than with economy and funding (Odén, 1991). However, investments in new positions in medicine and science were made in the 1950s (Odén, 1991). These measures, at least potentially, stimulated the research environment and attracted more people into graduate studies.

In contemporary political debate, medicine and science were regarded as prosperous fields (which is also a relevant description in quantitative comparisons with other fields), and policy makers hoped academic culture would spread to other domains (Odén, 1991). Graduate studies were, in some places and in many respects, re-

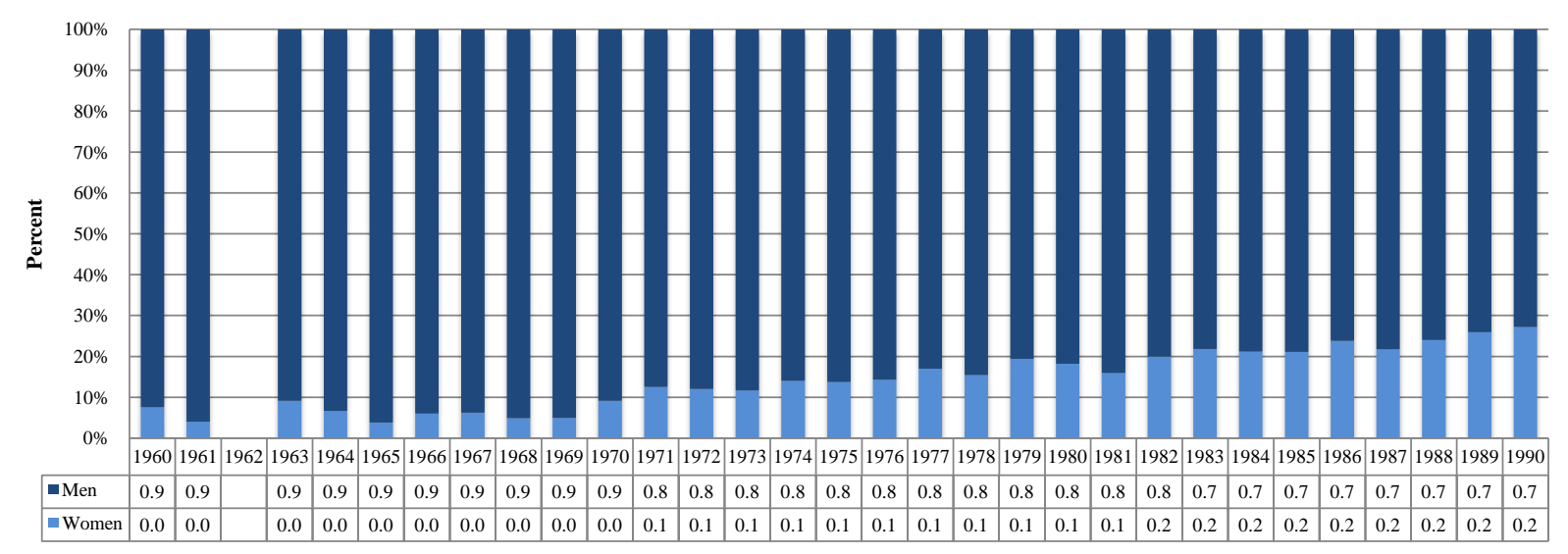

Figure 2. Gender balance in Ph.D. degrees, 1960-1990 (\%). Sources: Statistical Yearbook of Sweden, 1960-1972; primary reports from the administrative agency Statistics Sweden (1960-1972); "Statistical database" (1973-1990), Statistics Sweden. 

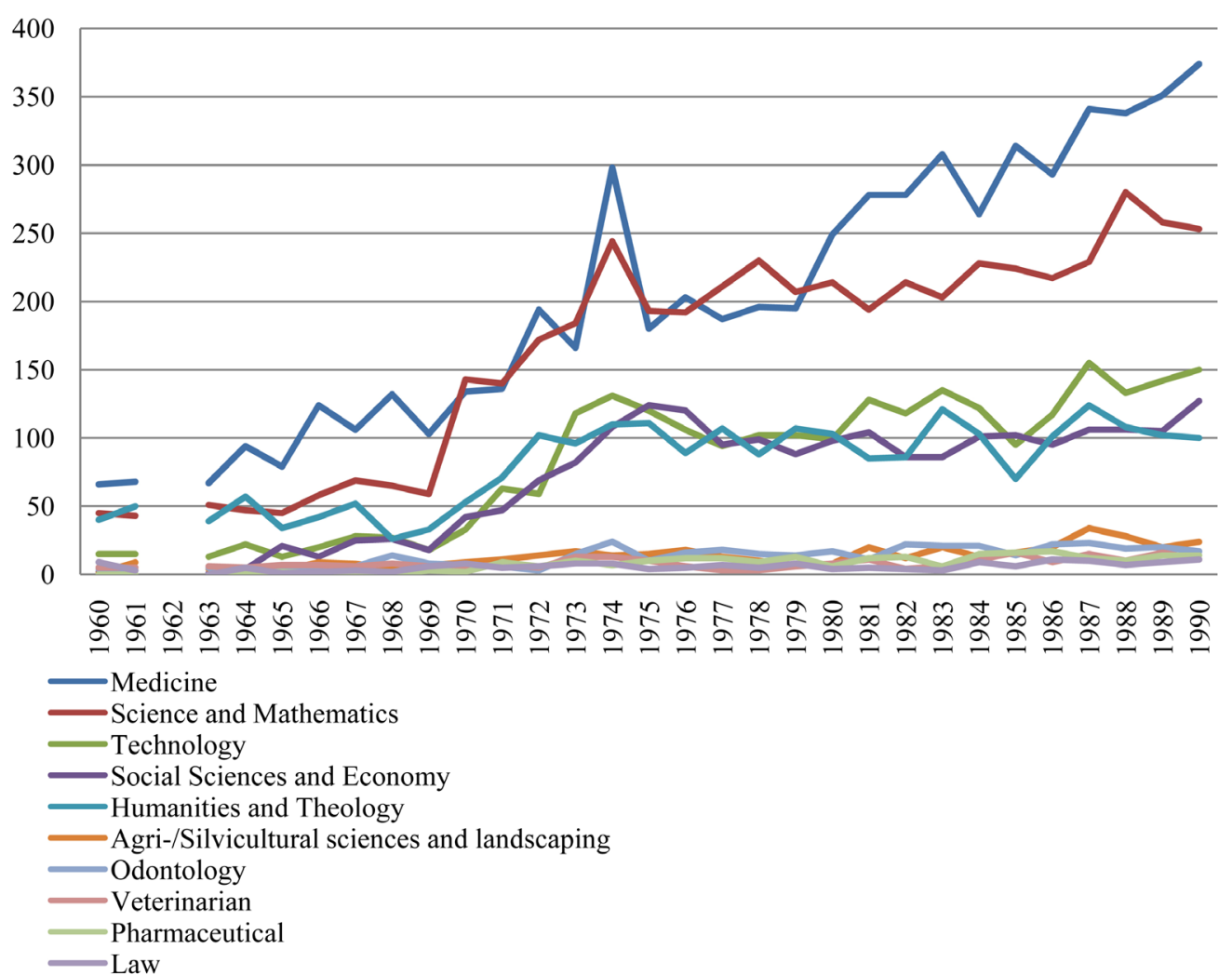

Figure 3. Ph.D. frequency, 1960-1990. Growth by disciplinary field (n). Sources: Statistical Yearbook of Sweden, 19601972; primary reports from the administrative agency Statistics Sweden (1960-1972); "Statistical database" (1973-1990), Statistics Sweden.

garded as cultivating activities for their own sake (Odén, 1991). Instead, research was to be considered as teamwork and not as a personal and/or individual matter (Odén, 1991; Segerstedt, 1966). The matter of culture was thereby directly connected to performance, and it was thought that a change in direction would in turn promote a higher throughput rate of graduate students (Odén, 1989). Its superstructure could be described as a "scientification" of society at the same time as research also became a part of society; metaphorically speaking, a dismantling of the ivory tower was eligible (Odén, 1989). The focus on efficiency in graduate studies with its fragmentation of scholarly knowledge and higher degree of red tape-processes has also been referred to as a de-qualification of academia (Gesser, 2015; Gesser, 1985). In spite of these intentions, the fields of social sciences and the humanities kept lagging behind and were thus in the spotlight for "recurrent political investigations, proposals and decisions" for several years to come (Odén, 1991). However, if this lag should be interpreted as an objection to change, and/or difficulties in shifting to a research system prizing teamwork or not,is another question.

In the early 1960s, before the expansion, Ph.D. graduates within the field of humanities accounted for approximately one quarter of all graduates. In the following years, a decline is evident and the share shrinks over time even though occasional increases can be identified; the substantial proportion moves roughly between 10 and 15 percent. In the first half of the 1960s, the social sciences show modest rates, but eventually the field reaches about the same levels as the humanities. The field of technology peaks in 1973 with Ph.D. making up 18 percent of the total number of graduates, but remains around 15 percent throughout the period as a whole. The ratio between fields during the whole time period is shown in Figure 4 below.

Approximately every fourth person earned a Ph.D. degree in science, while roughly every third person (and often more) did the same in medicine-with some exceptions in the 1970s when it had similar levels to the share of degrees in science. To summarize, Ph.D. graduates cluster within the disciplinary domains of medicine and science, whereas, the remaining eight fields form groups on two distinct lower levels (in terms of degree frequency, see Figure 3); Does this generate a noticeable gender-based crowding effect or not? 


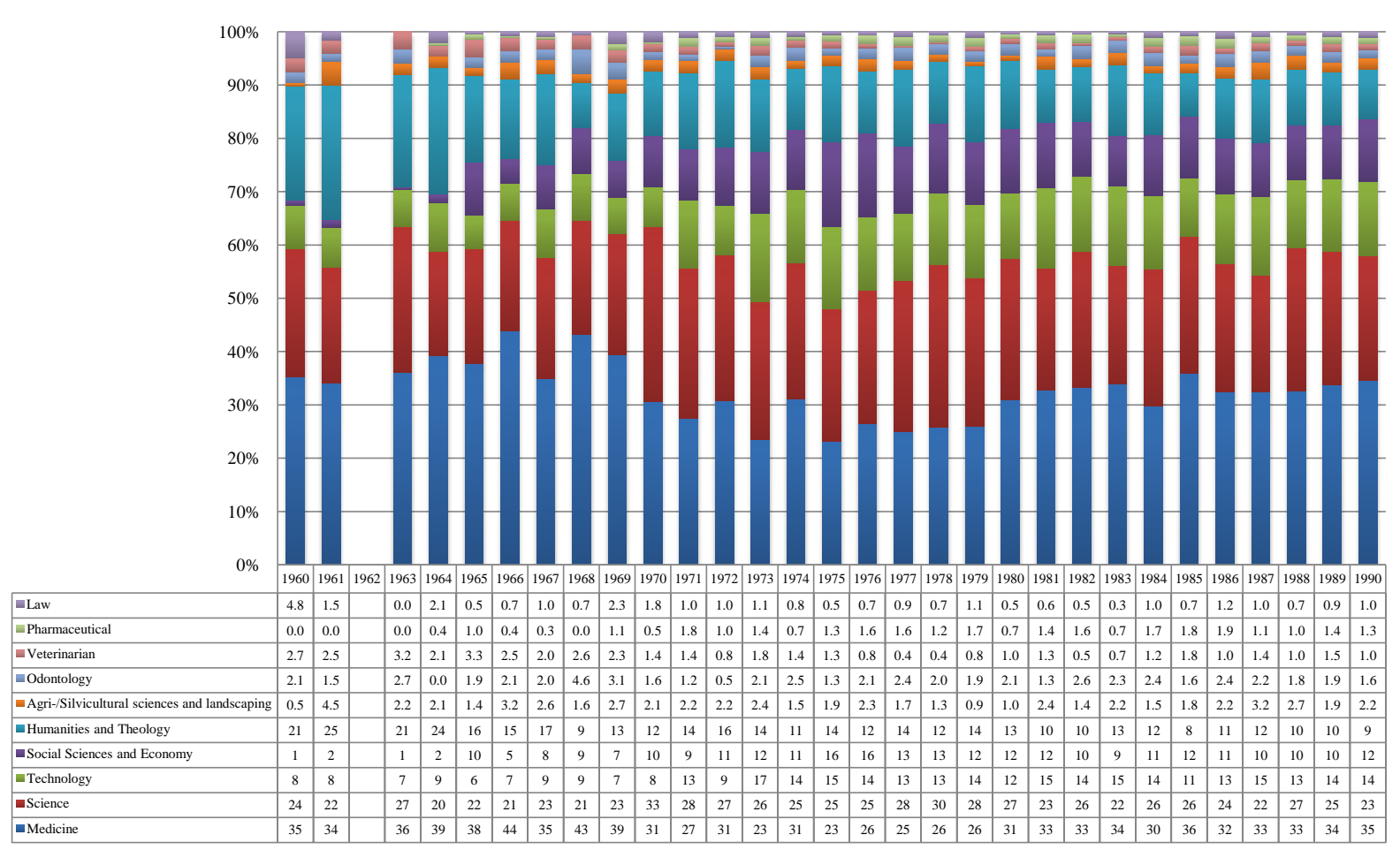

Figure 4. Ph.D. degrees: Proportions (\%) by disciplinary field, 1960-1990. Sources: Statistical Yearbook of Sweden, 19601972; primary reports from the administrative agency Statistics Sweden (1960-1972); "Statistical database” (1973-1990), Statistics Sweden.

\section{Gender Ratio and Crowding}

In this section, the gender ratio in disciplinary fields is examined. Since the volume between disciplinary domains varies significantly, results are presented in two separate diagrams. The proportionally smallest fields constitute less than five percent each of all fields (Figure 4), and since absolute numbers are also moderate $(>25)$, an assessment of crowding in these fields are left out ${ }^{9}$. Nevertheless, some results are noteworthy.

\subsection{Five Smallest Fields}

As displayed in Figure 5, women earned Ph.D. degrees in four out of five smaller fields during the first decade of the investigated time period. Less than ten individuals per field and year (with an exception for odontology in 1968 when 14 men graduated) were awarded degrees. In 1974, odontology peaked with 24 graduates of which five (21 percent) were women. The highest number of Ph.D.s in small fields across three decades is evident within the field of agricultural/silvicultural sciences and landscaping, which accounts for $34 \mathrm{Ph}$.D. graduates in $1987^{10}$. Three of these were women (9 percent).

Quantitatively, the number of degrees in each of the smaller fields increases over time with a visible development in the 1980s (it is important to note that there are still less than 34 degrees per year and field), but more strikingly the women's share increases in the second half of the time scope of this study (Figure 5). Thus, it is worth mentioning the gender ratio in the fields of pharmaceutical and veterinarian sciences as well as odontology. In the pharmaceutical field, the ratio of women with Ph.D. degrees swings between one-quarter and sixtenths, while the proportion of women within veterinarian science and odontology lands just below.

\subsection{Five Larger Fields}

A general look at the frequency of women being granted Ph.D.s within the larger fields indicates (Figure 6) an

${ }^{9}$ With two exceptions regarding absolute numbers within the agri- and silviocultural sciences which peaks in 1987 with 34 and drops to 28 the following year (and then to 20 in 1989).

${ }^{10}$ To note, this stands out since amount in odontology vary between 12 and 28 during the rest of the 1980s. 


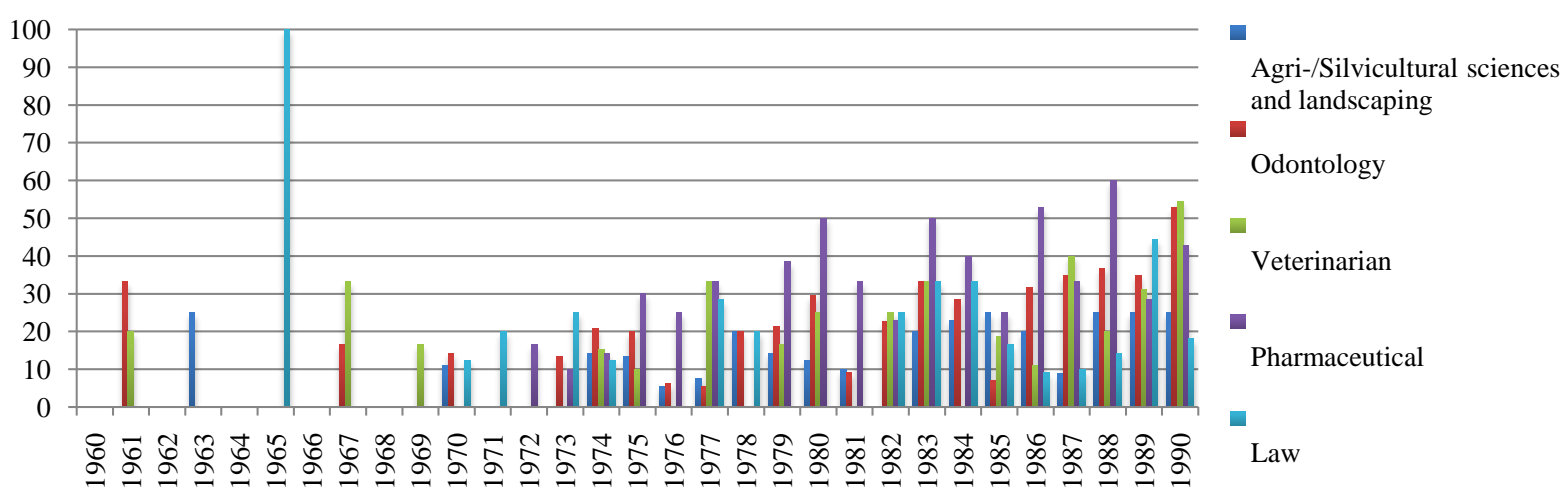

Figure 5. Proportion of women with Ph.D. degrees by smallest disciplinary domain, 1960-1990 (\%). Sources: Statistical Yearbook of Sweden, 1960-1972; primary reports from the administrative agency Statistics Sweden (1960-1972); "Statistical database" (1973-1990), Statistics Sweden.

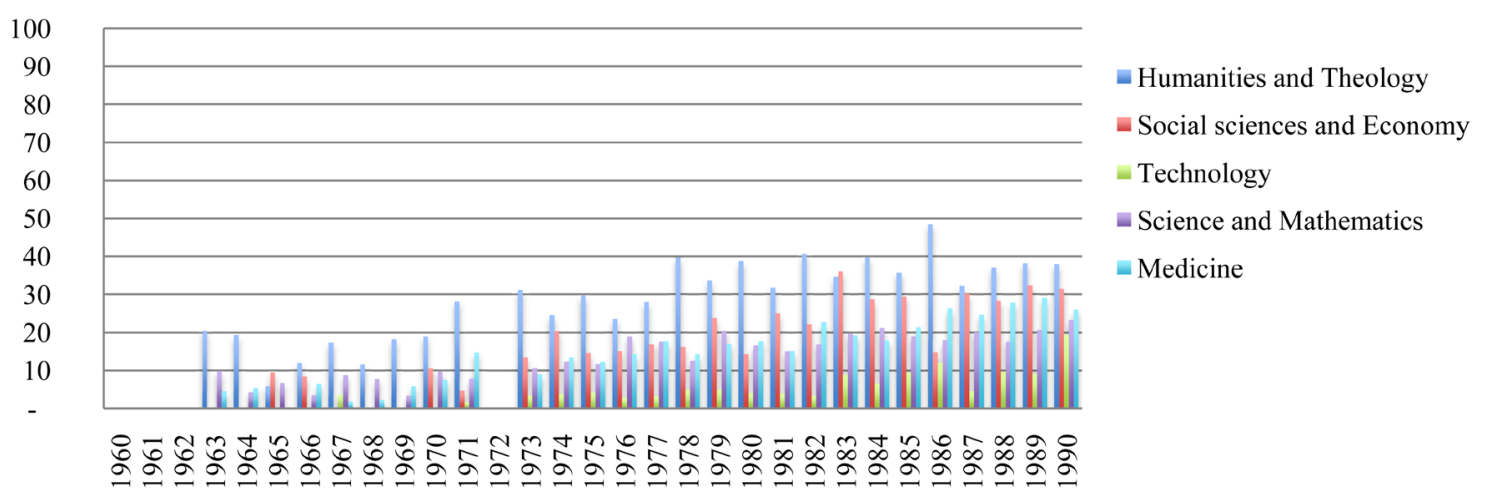

Figure 6. Proportion of women with Ph.D. degrees by largest disciplinary domain, 1960-1990 (\%). Sources: Statistical Yearbook of Sweden, 1960-1972; primary reports from the administrative agency Statistics Sweden (1960-1972); "Statistical database" (1973-1990), Statistics Sweden.

inverted distribution compared to the size of the fields (i.e. the total number of Ph.D.s). In keeping with the hypothesis of crowding, this impact is anticipated. The largest share of women is evident in the humanities, which is, moreover, one of the smaller disciplinary domains focused on here and where women comprised about 30 50 percent of all Ph.D. graduates during the 1970s and 1980s. In the 1960s, the ratio fluctuates from 21 percent in 1963 to 6 percent two years later. The field not only displays the largest share of women per field during the entire time period, but also represents the largest proportion of women in their distribution within the studied fields.

Within the field of medicine, where the highest numbers of Ph.D. degrees found, those granted to women increase from well below 10 percent in the 1960s to almost 20 percent in the following decade. Finally, in the 1980s, the ratio between men and women approaches 70/30. The same development is evident in the field of science; however, the ratio levels out in the last investigated decade. Finally, in the social sciences, women account for (with some exceptions) roughly 10 - 30 percent of all Ph.D.s within the field.

The smallest proportion of women is not found within the largest field but within the field of technology, which in turn belongs to the segment of fields that constitutes 20 percent or less of the total amount of Ph.D.s, i.e. well below the proportion in science and medicine. When the ratio increases by a few percentage points over time, the proportion of women also rises slightly.

The field of medicine displays the quantitatively steepest growth over the 30-year time span. During the 1980s, only Ph.D. degrees in this particular field appear to have increased (Ekehammar \& Löfgren, 1981). But this had, as indicated above, a relatively low impact on number of women with Ph.D.s. This might also suggest that a spill-over effect is not in play. Noticeable is also that data follows the gendered understanding and traditional coding of the fields. However, this changes in the years to come. A few years into the $21^{\text {st }}$ century the 
proportion of women with degrees in the male-dominated field of medicine accounted for 57 percent. In the field of technology, the ratio rose to about $1 / 4$, and within the humanities, women accounted for up to 58 percent of all Ph.D. graduates (Högskoleverket, 2006).

Overall, a pattern of crowding is visible, albeit not consistent and not without exceptions. Technology belongs to one of the smaller fields of the big five but contains the smallest share of women. Nevertheless, gender imbalances are greatest in the two fields with the highest numbers of Ph.D. graduates, i.e. the more crowded, the larger the disproportion. The field of medicine is dominant throughout all three decades, with a few exceptions in the 1970s when science challenges its supremacy. The following section focuses on periods of accelerated growth and to what extent this interplays with gender ratio patterns.

\section{Fields and Spill-Over Effects}

The existing narrative suggests that investments in higher education on different levels (funding, financial structure, number of supervisors, etc.) during the 1960s stimulated a general increase in Ph.D.-student enrollment and graduation (Högskoleverket, 2006). The necessity for efficiency had been advocated in several government official reports and investigations (Högskoleverket, 2006). In keeping with the theory of spill-over effects, this section of the article addresses phases of substantial increases in the number of granted Ph.D. degrees. To what extent (if any) were these upturns simultaneously accompanied by a proportionally greater increase in Ph.D.s earned by women?

\subsection{General Increase 1969-1974}

As already shown in Figure 3, all fields experienced a tangible increase between 1969 and 1974/1975, the period in which the graduate education level underwent several formal changes. The growth was, with a few exceptions, both preceded and followed (immediately or with a slight delay) by a more or less significant decline in numbers (Table 4).

To assess the occurrence of a spill-over effect during this particular period of expansion, the relative increase in the proportion of women Ph.D. graduates is compared to the relative increase in each field in total. A comparison of growth within each field between 1969 and 1974 (note, not the average increase throughout each year) results in the following ranking (Table 5).

A significant growth is evident in all fields, and the question is if this massive increase generated an accelerated increase in the number women with Ph.D.s. To keep in mind is the fact that the numbers of women are small (fewer than 40 individuals/field), and local shifts (university specific) can have large effects on general patterns. Nevertheless, how do these findings—increases and decreases-correspond with overall cycles? To what extent is the ratio between men and women affected by this expansion?

Trends in the number of women earning Ph.D. degrees show a convincing increase over time, but with obvious fluctuations. The clustering of fields differs—as do other trends as well—from the patterns evident in Figure 3, which depicts the development in total numbers (men and women). As displayed in Figure 7 above, four out of ten fields show a modest increase, and in the disciplinary domain of law, the number of women are less than four (and for several years nil) per year. As shown in Table 7 below, an increase in the amount of

Table 4. Period of expansion in disciplinary domains, 1967-1976. Ph.D. degrees (n) ${ }^{11}$.

\begin{tabular}{|c|c|c|c|c|c|c|c|c|c|c|}
\hline & 1967 & 1968 & 1969 & 1970 & 1971 & 1972 & 1973 & 1974 & 1975 & 1976 \\
\hline Medicine & 106 & 132 & 103 & 134 & 136 & 194 & 166 & 298 & 180 & 203 \\
\hline Science and math. & 69 & 65 & 59 & 143 & 140 & 172 & 184 & 244 & 193 & 192 \\
\hline Technology & 28 & 27 & 18 & 33 & 63 & 59 & 118 & 131 & 120 & 106 \\
\hline Social sciences & 25 & 26 & 18 & 42 & 47 & 69 & 82 & 108 & 124 & 120 \\
\hline The humanities and theol. & 52 & 26 & 33 & 53 & 71 & 102 & 96 & 110 & 111 & 89 \\
\hline
\end{tabular}

Sources: Statistical Yearbook of Sweden, 1960-1972; Primary reports from the administrative agency Statistics Sweden (1960-1972); “Statistical database" (1973-1990), Statistics Sweden.

\footnotetext{
${ }^{11}$ The five largest disciplinary domains, i.e. domains with more than 50 Ph.D.s granted per year.
} 


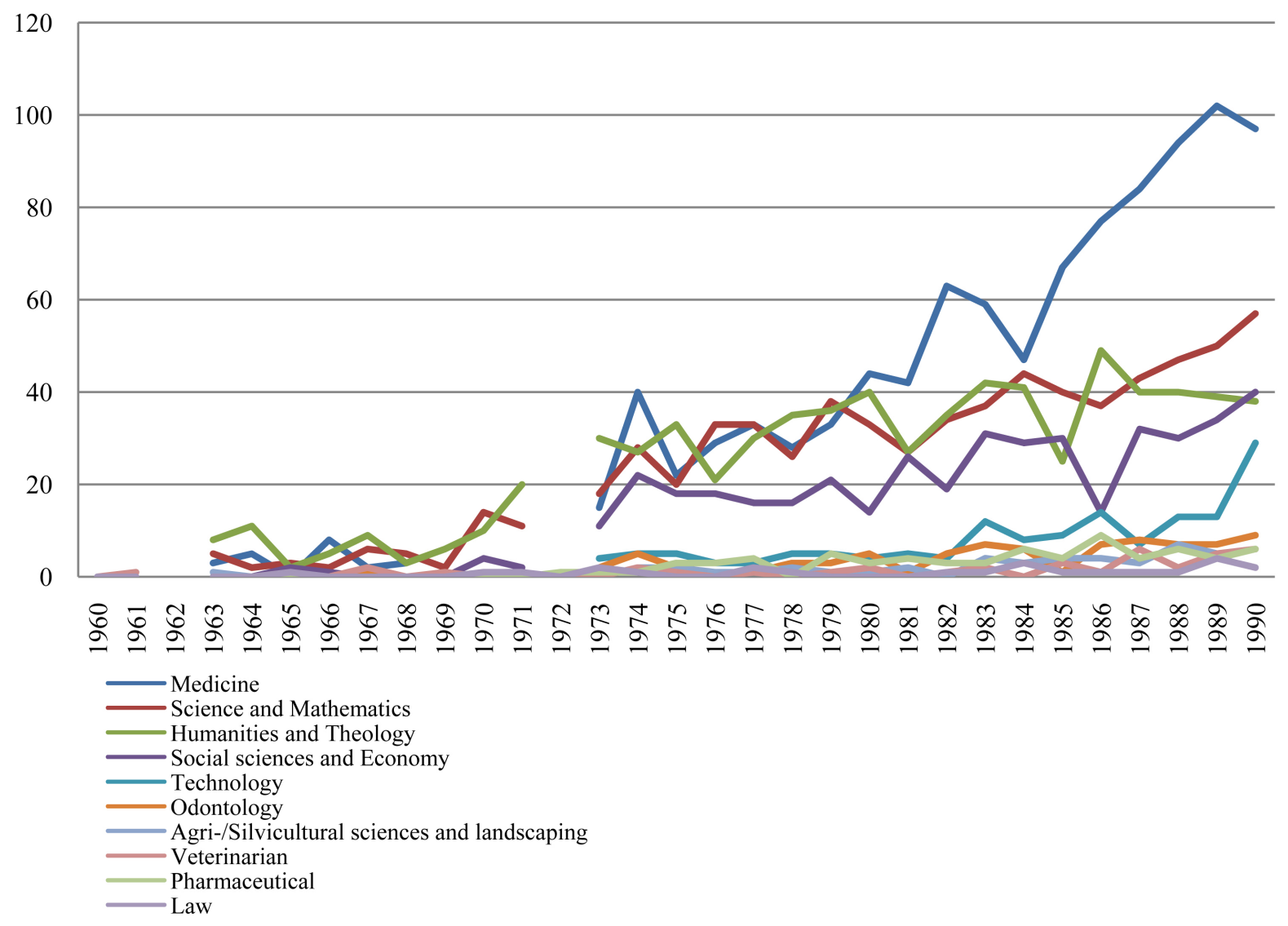

Figure 7. Female Ph.D. graduates by disciplinary field, 1960-1990 (n). Sources: Statistical Yearbook of Sweden, 1960-1972; primary reports from the administrative agency Statistics Sweden (1960-1972); "Statistical database" (1973-1990), Statistics Sweden.

Table 5. Proportional increase in fields from 1969 to 1974, descending (\%).

\begin{tabular}{cc}
\hline Disciplinary domain & Increase (\%) \\
\hline Technology & 728 \\
Social Sciences & 600 \\
Science and math. & 414 \\
The humanities and theol. & 333 \\
Medicine & 289 \\
\hline
\end{tabular}

women during the massive growth in Ph.D. graduates from 1969-1974 can be identified, but numbers are small and the annual rise in proportions is not overwhelming.

The humanities hold the largest share of women throughout these years (with an increase from 18 to 25 percent) even though actual numbers decline. The most striking feature during these years might be the fact that the field of medicine - which at the same time displays the slowest general increase-rises from a low proportion of women to a high of 15 percent in 1971 and a second best of 13 percent in 1974. A possibly unexpected result is that the fields of science and social sciences more or less break-even slightly behind the field of medicine. In relation to general increase patterns, a spill-over effect can hardly be noticed in this five year-period since the largest proportional growth is identified within the field technology followed by social sciences and science (Table 6). In the years to come, periods of patterns between fields differ. Thus, to what extent a spill-over effect is evident during these phases is examined in the following section. 


\subsection{Field Specific Increase}

Field specific trends in increase and temporary decrease are depicted in Figure 3, and as mentioned earlier, the general increase accelerates to various degrees over time. A closer look at the data (Figure 7) show that the field of medicine counts for the quantitatively largest number of Ph.D.-graduating women, but with an exception in 1975 to 1980 when the number of women within science and the humanities reaches the same level (subsequent to the so-called artificial peak in 1974). By the end of the investigated time period, the number of women with doctorates in the field of technology is closing in on the social sciences, while the numbers of women within the humanities are declining. The gap between women in medicine and the other fields widens in the 1980s, but seems to decrease at the end of the decade. At some points in time, but not quite simultaneously, the fields of technology, social sciences, and the humanities show significant decreases in women. Over time, fluctuations in the number of women seem more prevalent than their total numbers. This section focuses on the correlation of the total increase of Ph.D. degrees awarded in each field with in the corresponding proportion of women. The latter is displayed in Table 7.

The highest proportion of women is found in 1986 within the humanities, where women constituted 49 percent of all Ph.D. graduates. This occurs at a point in time where the number of Ph.D. degrees within this particular field is recovering from a distinct dip (Table 8), but where the total numbers are trending upwards (Dia-

Table 6. Female Ph.D. graduates, 1969-1974 (n), share in parentheses (\%).

\begin{tabular}{ccccccc}
\hline & $\mathbf{1 9 6 9}$ & $\mathbf{1 9 7 0}$ & $\mathbf{1 9 7 1}$ & $\mathbf{1 9 7 2}$ & $\mathbf{1 9 7 3}$ & $\mathbf{1 9 7 4}$ \\
\hline Medicine & $6(6)$ & $10(7)$ & $20(15)$ & - & $15(9)$ & $40(13)$ \\
Science and math. & $2(3)$ & $14(10)$ & $11(8)$ & - & $18(11)$ & $28(12)$ \\
Technology & $-(0)$ & $-(0)$ & $1(2)$ & - & $4(3)$ & $5(4)$ \\
Social sciences & $-(0)$ & $4(11)$ & $2(5)$ & - & $11(13)$ & $22(10)$ \\
The humanities and theol. & $6(18)$ & $10(19)$ & $20(28)$ & - & $30(31)$ & $27(25)$ \\
\hline
\end{tabular}

Table 7. Proportion of Ph.D. degrees awarded to women by disciplinary domain, 1975-1990 (\%) ${ }^{12}$.

\begin{tabular}{|ccccccccccccccccc}
\hline & 1975 & 1976 & 1977 & 1978 & 1979 & 1980 & 1981 & 1982 & 1983 & 1984 & 1985 & 1986 & 1987 & 1988 & 1989 & 1990 \\
\hline Medicine & 12 & 14 & 18 & 14 & 17 & 18 & 15 & 23 & 19 & 18 & 21 & 26 & 25 & 26 & 29 & 26 \\
Science \& math. & 12 & 19 & 16 & 11 & 18 & 15 & 14 & 16 & 18 & 19 & 18 & 17 & 19 & 17 & 19 & 23 \\
Technology & 4 & 3 & 3 & 5 & 5 & 4 & 4 & 3 & 9 & 7 & 10 & 12 & 5 & 10 & 9 & 19 \\
Social sciences & 15 & 15 & 17 & 19 & 23 & 14 & 25 & 22 & 36 & 29 & 29 & 15 & 30 & 28 & 32 & 32 \\
Hum. \& theol. & 30 & 24 & 28 & 40 & 34 & 39 & 32 & 40 & 35 & 40 & 36 & 49 & 32 & 37 & 38 & 38 \\
\hline
\end{tabular}

Sources: "Statistical database” (1973-1990), Statistics Sweden. Peaks in pink, and decreases in yellow.

Table 8. Ph.D. degrees by disciplinary domain, 1977-1990 (n) ${ }^{13}$.

\begin{tabular}{|c|c|c|c|c|c|c|c|c|c|c|c|c|c|c|}
\hline & 1977 & 1978 & 1979 & 1980 & 1981 & 1982 & 1983 & 1984 & 1985 & 1986 & 1987 & 1988 & 1989 & 1990 \\
\hline Medicine & 187 & 196 & 195 & 249 & 278 & 278 & 308 & 264 & 314 & 293 & 341 & 338 & 351 & 374 \\
\hline Science \& math. & 211 & 230 & 208 & 214 & 194 & 214 & 203 & 228 & 224 & 217 & 229 & 280 & 258 & 253 \\
\hline Technology & 94 & 102 & 102 & 99 & 128 & 118 & 135 & 122 & 95 & 117 & 155 & 133 & 142 & 150 \\
\hline Social sciences & 95 & 99 & 88 & 98 & 104 & 86 & 86 & 101 & 102 & 95 & 106 & 106 & 105 & 127 \\
\hline Hum. \& theol. & 107 & 88 & 107 & 103 & 85 & 86 & 121 & 103 & 70 & 101 & 124 & 108 & 102 & 100 \\
\hline
\end{tabular}

Sources: "Statistical database” (1973-1990), Statistics Sweden. Highest numbers are highlighted.

\footnotetext{
${ }^{12}$ Five largest disciplinary domains, i.e. domains with more than 50 Ph.D.s awarded per year.

${ }^{13}$ Five largest disciplinary domains, i.e. domains with more than 50 Ph.D.s per year.
} 
gram 1). The second highest proportion is found within the social sciences, which, in 1983, reaches a level of 36.0 percent. However, the absolute figures are relatively small and the number of women increases when the field as a whole is decreasing. Therefore, the ratio is not an effect of a general influx in the field; decreases or plateaus can instead explain other peaks in the women's share of the total numbers of Ph.D.-degree frequency. In addition to this, small increases in the number of women generate large changes in percentage.

Within the disciplinary domain of medicine, the highest ratio is 29 percent in 1989. This field increases steadily (with a few slopes) but not as a result of a proportionally larger growth in women. On the contrary, the increase within the field does not seem to have generated an influx of women completing their Ph.D. degrees. Both the fields of science and technology reach a ratio of about 1/5 in the last examined year of the period. Within science, total numbers decrease (with the largest in 1988), whereas in the case of technology (which peaked in 1987 and then dropped by 14 percent) figures increase. Nevertheless, in neither of these cases is the larger proportion of women a result of a massive and/or rapid increase of Ph.D. graduates in general in these particular fields. In addition to this, the growing proportion of women by field cannot-as a spill-over effect in this regard-be explained as a function of an accelerating expansion of Ph.D.s awarded to women in general.

\section{Discussion}

This article addresses the ratio of women in Swedish academia on the graduate level, more specifically the distribution of Ph.D. degrees in/and between disciplinary domains, during the expansion era in higher education. In the decades succeeding World War II, the Swedish educational system underwent pervasive (ideological) changes, which, among other things, aimed to channel a larger part of the population into higher education. This was a matter of national interest; it was thought that increased attainment in undergraduate studies would enhance the level of competence and in extension help promote Sweden as a cutting-edge country in research. Of special interest in this study has been the (possible) correlation between periods of substantial growth in degrees on the graduate level and gender balance.

Two different approaches, derived from two studies of contemporary patterns in gender distribution by disciplinary domain, have served as starting points. First, the pattern of crowding was assessed. The concept of crowding refers to contemporary EU-data, which indicate that fields with a proportionally smaller share of the total number of Ph.D. graduates show a higher level of gender balance. Second, the effect of what is referred to as spill-over has been tested to see if a general increase or increase of women in one area influences gender balance in other areas. Spill-over effects are evident on the undergraduate level in eight European countries. Thus, the purpose of the conducted study was to analyze-and to historicize- the impact of these mechanisms on the gender ratio of Ph.D. degree frequency increase in Sweden from 1960-1990.

The presented data was grouped into ten disciplinary domains (or fields) out of which half were quantitatively significantly smaller than the rest. The other five fields clustered in two groups, distinctly separated by magnitude in numbers: topmost, the largest fields of medicine and science, followed by technology, social sciences, and the humanities. Quantitatively and over time, these five fields unveil four distinct patterns: 1) All fields undergo a massive increase in numbers during the years of reform 1960-1974; 2) The field of medicine is by far the largest, although science keeps pace and actually takes the lead from 1976-1979 when the number of Ph.D. degrees decreased and stagnated in the aftermath of the so-called artificial peak of 1974; 3) The apparent gap between the two clusters of fields is also evident during the 1970s; 4) From 1979 and onwards another gap is evident, namely a growing split between medicine and science.

Trends and ratios for women with Ph.D. degrees on an aggregated level show a gradual increase that starts to rise in conjunction with the massive growth from 1969 to 1974. This general expansion does not entail a boom in the ratio of women, although the numbers of women increases exponentially over these five years; however, during the 1960s, women were scarce. There is a gradual, stead increase throughout the whole period, but the gender gap remains wide on aggregated level; for example, in 1990, only one in four Ph.D. graduates was a woman. A closer look field by field provides a more elaborate picture, and the crucial question is if size matters, i.e. do crowded fields reveal greater gender imbalance than less crowded ones?

The fields were sorted by size and studied in two separate groups. The group containing the five smallest fields accounted for less than five percent of the total (and $<34$ individuals/field); therefore, these fields were not crowded to any extent. Nevertheless, the proportion of women starts to increase in the late 1970s, and the field of pharmacy stands out as being close to reaching gender balance. The five larger fields, constituting the second crowding-assessed group, divide into two clusters. A correlation between the proportionally smallest field and 
the largest share of women is confirmed within the humanities. However, the proportionally largest field (medicine) does not show the lowest ratio of women. The field of science, which is proportionally smaller, displays a greater gender imbalance-especially at the end of the investigated time period. The field in the second group with smallest share of women is technology, which (along with social sciences) is the proportionally smallest field of the big five. How do these facts correspond with the second point of departure, the question of spill-over effects?

The second group, i.e. the so-called big five, was assessed for spill-over influence on gender balance. The artificial peak in 1969-1974, when all fields underwent a massive increase, did not conclusively cause a corresponding upswing among women. In addition, in the following years, declines or stagnation in total numbers affect gender balance rather than substantial growth in general; general upturns do not cause a proportionally greater increase in women with graduate degrees. In sum, developments in gender ratios and growth patterns in total numbers do not indicate a spill-over effect.

Although the women's movement coincided with the tail end of the implementation of the new directives and admittance practices for university Ph.D. programs in 1969-1974, questions of gender equality were never really in the forefront (Markusson Winkvist, 2014). Rather, these reforms were designed to create more professional institutions that would produce both cutting-edge research and more highly qualified doctorates. Both of these new products would potentially enhance local, national, and university communities. The new 1960s/70s policies enlarged some fields (and resulted in the constriction of others), but the advancement of women within these fields has had a ceiling of sorts.

After the general upturn in the early 1970s, the relative gender gap in each disciplinary domains cannot exclusively be described as a successively, yet slowly, diminishing gap. The narrative of a linear process over time resulting in enhanced gender balance (in quantitative terms) on the graduate level needs to be supplemented with the fact that patterns of gender inequality in academia have persisted. The integration of women into traditionally male fields is still slow. Numbers of women in higher education rose, but percentages did not improve at a rate that boded well for an equal labor market in the near future. The rising numbers of women in higher education — a product of institutional changes rather than equality policies—mask this reality. Furthermore, a government policy that does not directly address gender equality will likely reproduce pre-existing inequalities, even in a country like Sweden, which has directly addressed gender inequality in so many other areas.

\section{Support}

Valuable comments and advice have generously been provided by Prof. Maria Sjöberg, Dr. Sara Ellis Nilsson, Dr. Rachel Pierce, and members of the Modern and Contemporary History Seminar at the Dept. of Historical Studies, University of Gothenburg. The study has been made possible through funding from Riksbankens Jubileumsfond [The Swedish Foundation for Humanities and Social Sciences].

\section{References}

Acker, J. (1990). Hierarchies, Jobs, Bodies: A Theory of Gendered Organisations. Gender \& Society, 4, 139-158. http://dx.doi.org/10.1177/089124390004002002

Acker, J. (2006). Inequality Regimes. Gender, Class, and Race in Organizations. Gender \& Society, 20, 441-464. http://dx.doi.org/10.1177/0891243206289499

Addis, E. (2010). Scientific Excellence. Meta-Analysis of Gender and Science Research-Topic Report. 7th RTD Framework Programme of the European Union (RTD-PP-L4-2007-1).

Andersson, A. (2007). “Vi blev antagligen för många”. Könskränkande behandling i akademisk miljö ["We Were Probably Too Many”. Gender Offensive Treatment in Academia]. Dissertation, Uppsala: Uppsala University.

Arbetsmiljöverket (2013). Under luppen-genusperspektiv på arbetsmiljö och arbetsorganisation. Kunskapssammanställning [Under the Microscope-Gender Perspective on Working Environment]. Rapport 2013:1.

Astin, H. S., \& Bayer, A. E. (1979). Pervasive Sex Differences in the Academic Reward System. Scholarship, Marriage, and What Else? In D. R. Lewis, \& W. E. Becker Jr. (Eds.), Academic Rewards in Higher Education (pp. 221-229). Cambridge, MA: Ballinger Pub. Co.

Barone, C. (2011). Some Things Never Change: Gender Segregation in Higher Education across Eight Nations and Three Decades. Sociology of Education, 84, 157-176. http://dx.doi.org/10.1177/0038040711402099

Billard, L. (1994). Twenty Years Later. Is There Parity for Academic Women? Thought and Action, 10, 114-144. 
Boring, A., Ottoboni, K., \& Stark, P. (2016). Student Evaluations of Teaching (Mostly) Do Not Measure Teaching Effectiveness. ScienceOpen Research, 1-11.

https://www.scienceopen.com/document/vid/818d8ec0-5908-47d8-86b4-5dc38f04b23e

Bourdieu, P. (2001). Masculine Domination. Redwood City, CA: Stanford University Press.

Chrapkowska, C. (2006). Akademins anrikning av män: en studie av svensk utbildningsstatistik 1957-2002 [Male Inrichment in Academia: A Study on Swedish Education Statistics 1957-2002]. Uppsala: Uppsala Universitet.

David, M. E. (2014). Feminism, Gender and Universities. Politics, Passion and Pedagogies. Farnham: Ashgate Publishing Ltd.

Ekehammar, B. (1982). Kvinnor och män före forskarutbildningen. Attityder, värderingar, val [Women and Men before Graduate Studies. Attitudes, Values, Choices]. In Kvinnor och män och forskning [Women and Men and Research]. UHÄ-Rapport 1982:4, Stockholm: Universitets-och högskoleämbetet.

Ekehammar, B., \& Löfgren, E. (1981). Kvinnor och män i högre utbildning och forskning. Trender och tendenser [Women and Men in Higher Education and Research. Trends and Tendencies]. UHÄ-Rapport 1981:20, Stockholm: Universitetsoch högskoleämbetet.

European Commission (2013). She Figures 2012. Gender in Research and Innovation. Statistics and Indicators. Luxembourg: Publications Office of the European Union. http://ec.europa.eu/research/science-society/document_library/pdf_06/she-figures-2012_en.pdf

European Commission (2015) She Figures 2015. Gender in Research and Innovation. Statistics and Indicators. Luxembourg: Publications Office of the European Union.

https://ec.europa.eu/research/swafs/pdf/pub_gender_equality/she_figures_2015-leaflet-web.pdf

Gesser, B. (1985). Utbildning, jämlikhet, arbetsdelning [Education, Equality, Labor Division]. Lund: Arkiv.

Gesser, B. (2015). Utbildning, jämlikhet, arbetsdelning [Education, Equality, Labor Division]. Med förord av Anders Persson. Lund: Arkiv.

Grove, J. (2013). At the Heart of the Higher Education Debate. The Times Higher Education, Global Gender Index 2013. http://www.timeshighereducation.co.uk/features/global-gender-index-2013/2003517.fullarticle

Högskoleverket (2006). Högre utbildning och forskning 1945-2005: En översikt [Higher Education and Research 19452005]. Stockholm.

Husén, T., \& Härnqvist, K. (2000). Begåvningsreserven. En återblick på ett halvsekels forskning och debatt [Broadend Student Recruitment. A Review of Research and Debate from a Half-Century Perspective]. Uppsala: Föreningen för svensk undervisningshistoria.

Husu, L. (2005). Dold könsdiskriminering på akademiska arenor. Osynligt, synligt, subtilt [Hidden Gender Discrimination in Academia. Invisible, Visible, Subtle]. Stockholm: Högskoleverket.

Husu, L., \& de Cheveigné, S. (2010). Gender and Gatekeeping of Excellence in Research Funding: European Perspectives. In B. Riegraf, B. Aulenbacher, E. Kirsch-Auwärter, \& U. Müller (Eds.), Gender Change in Academia: Re-Mapping the Fields of Work, Knowledge, and Politics from a Gender Perspective (pp. 43-59). VS Verlag für Sozialwissenschaften. http://dx.doi.org/10.1007/978-3-531-92501-1_4

Johansson, M., \& Katz, K. (2007). Underutnyttjad utbildning och lönegapet mellan kvinnor och män [Underused Education and the Wage Gap between Women and Men]. Uppsala: Institutet för arbetsmarknadspolitisk utvärdering (IFAU).

Lamont, M. (2009). How Professors Think. Inside the Curious World of Academic Judgment. Cambridge, MA: Harvard University Press. http://dx.doi.org/10.4159/9780674054158

Marklund, S. (1982). Skolsverige 1950-1975. D. 3, Från Visbykompromissen till SIA [School in Sweden 1950-1975. Part 3, From the Visby Compromise to SIA]. Stockholm: Liber/Utbildningsförl.

Markusson Winkvist, H. (2014). Perspektiv på begåvningsreserven [Perspectives on the Broadening of Student Recruitment]. Lychnos, Årsbok för idé-och lärodomshistoria, 105-123.

Mason, M. A., Wolfinger, N. H., \& Goulden, M. (2013). Do Babies Matter? Gender and Family in the Ivory Tower. New Brunswick, NJ: Rutgers University Press.

Melin, G. (2007). Reviewing Applications by Women. Critical Use of Additive and Reasoning Evaluation Methods. Stockholm: SISTER.

Öberg, A. D., \& Öberg, T. (2013). Lönekamp med förhinder: Om kvinnolöner i vård och verkstad [Obstructed Wage Struggle: On Women's Payment in Care and Workshop Sectors]. Stockholm: Premiss.

Odén, B. (1989). Forskarutbildning och politik [Graduate Studies and Politics]. In T. Nybom (Ed.), Universitet och samhälle [University and society]. Om forskningspolitik och vetenskapens samhälleliga roll. Stockholm: Tidens förlag.

Odén, B. (1991). Forskarutbildningens förändringar 1890-1975: Historia, statskunskap, kulturgeografi, ekonomisk historia [Changes in Graduate Studies 1890-1975: History, Political Science, Cultural Geography, Economic History]. Lund: Lund University Press. 
Persson, A. (1998). Studentinflytande i massuniversitetet [Student Influence in Institutions of Mass Higher Education]. Rapport nr 98:204, Utvärderingsenheten, Lunds Universitet.

Ramirez, F. O., \& Wotipka, C. M. (2001). Slowly but Surely? The Global Expansion of Women’s Participation in Science and Engineering Fields of Study, 1972-1992. Sociology of Education, 74, 231-251.

http://dx.doi.org/10.2307/2673276

Rosenbeck, B. (2014). Har videnskaben køn? Kvinder i forskning [Does Science and Scholarship Have a Gender? Women in Research]. Museum Tusculanums Forlag: Københavns Universitet.

Sandström, U., Wold, A., \& Jordansson, B. (2010). Hans Excellens. Om miljardsatsningarna på starka forskningsmiljöer [His Excellence. On Billion Investments in Strong Research Settings]. Stockholm: Delegationen för jämställdhet i högskolan (DJ).

Schiebinger, L. (1999). Has Feminism Changed Science? Cambridge, MA: Harvard University Press. http://dx.doi.org/10.7788/figurationen.1999.0.0.50

Schofer, E., \& Meyer, J. W. (2005). The Worldwide Expansion of Higher Education in the Twentieth Century. American Sociological Review, 70, 898-920. http://dx.doi.org/10.1177/000312240507000602

Segerstedt, T. (1966). Den akademiska gemenskapen [The Academic Community]. Uppsala: En sociologisk skiss.

Silander, C. (2010). Pyramider och pipelines: Om högskolesystemets påverkan på jämställdhet i högskolan [Pyramides and Pipelines: The System of Higher Education and Its Effect on Gender Equality]. Dissertation Linnéuniversitetet, Växjö.

Statistical Database (1973-1990). Statistics Sweden.

http://www.statistikdatabasen.scb.se/pxweb/sv/ssd/?rxid=1808da90-4fb7-4c04-b0d8-ae6a10075104

Statistical Yearbook of Sweden (1945-1981). Statistics Sweden. Stockholm.

Statistics Sweden (1960-1972). Primary Reports.

UHÄ (1982). Kvinnor och män och forskning. Rapport 1982:4, Stockholm.

Wennerås, C., \& Wold, A. (1997). Nepotism and Sexism in Peer-Review. Nature, 387, 341-343. http://dx.doi.org/10.1038/387341a0

Žáková, P. (2013). Sun spots on the Swedish Labour Market. ECFIN Country Focus, 10, 1-10. 


\section{Appendix}

\section{A. Gender ratio per disciplinary domain}

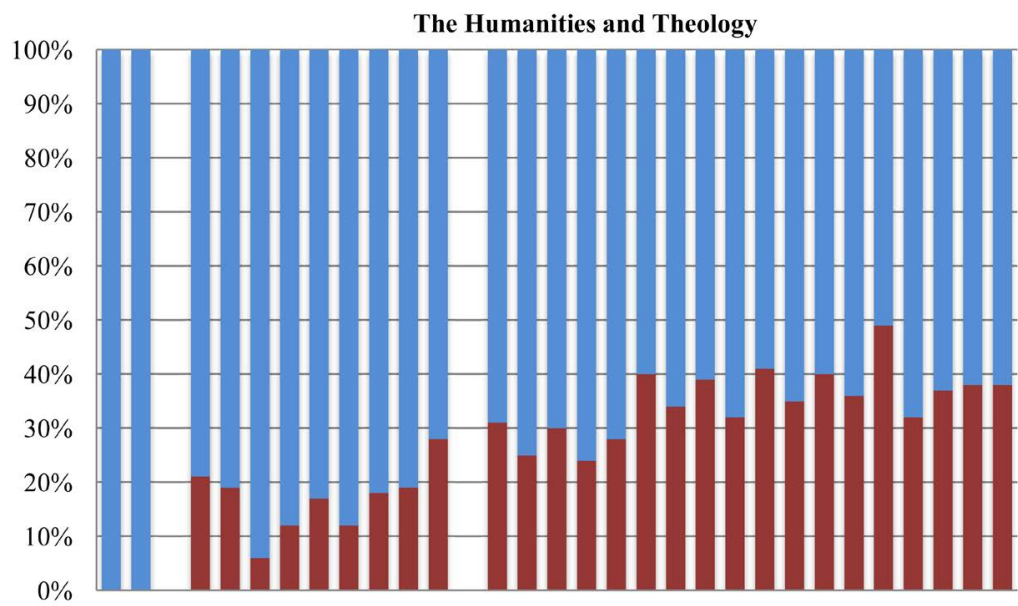

Men

- Women

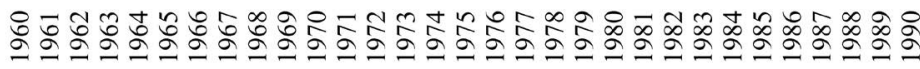

Social Sciences

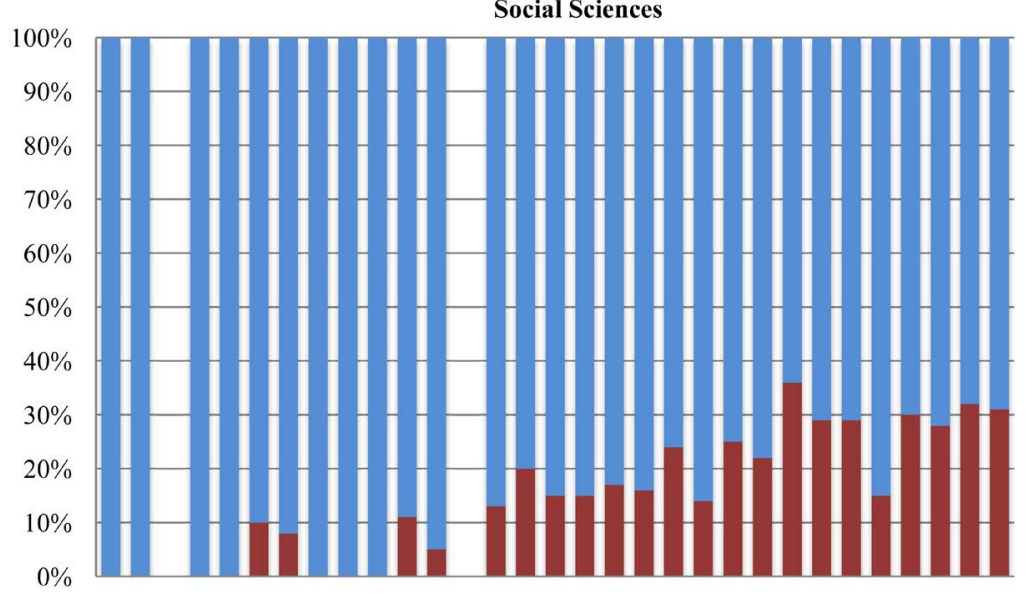

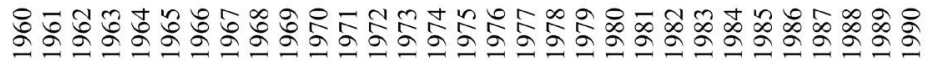

Technology

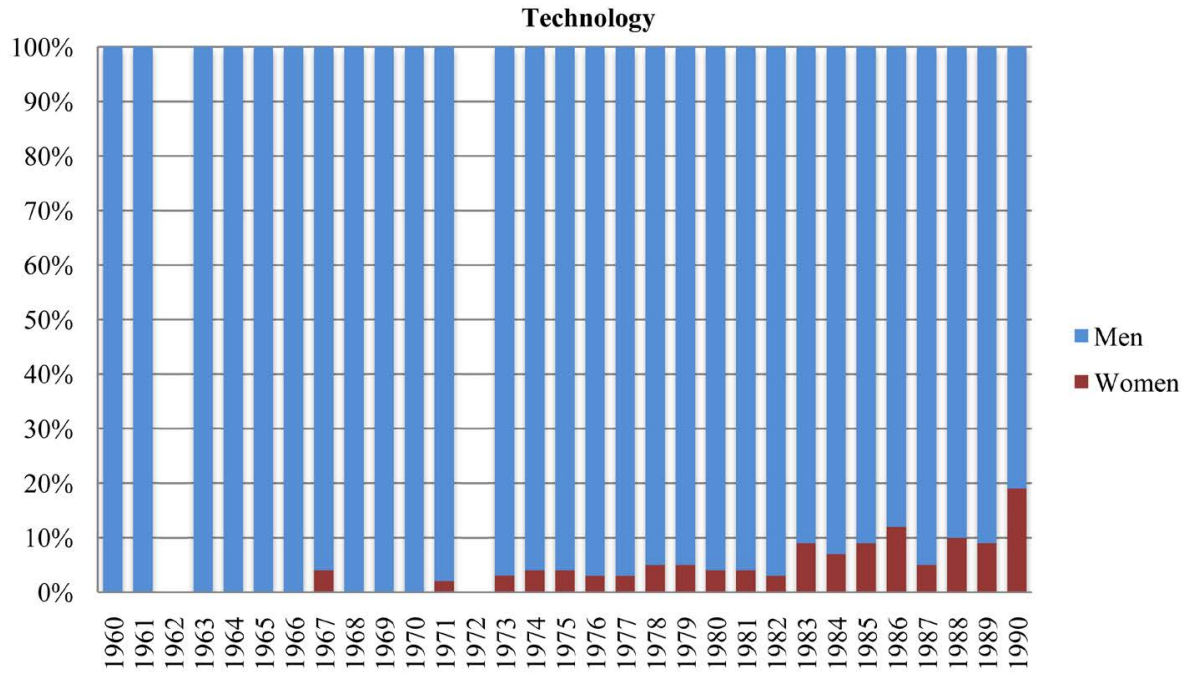



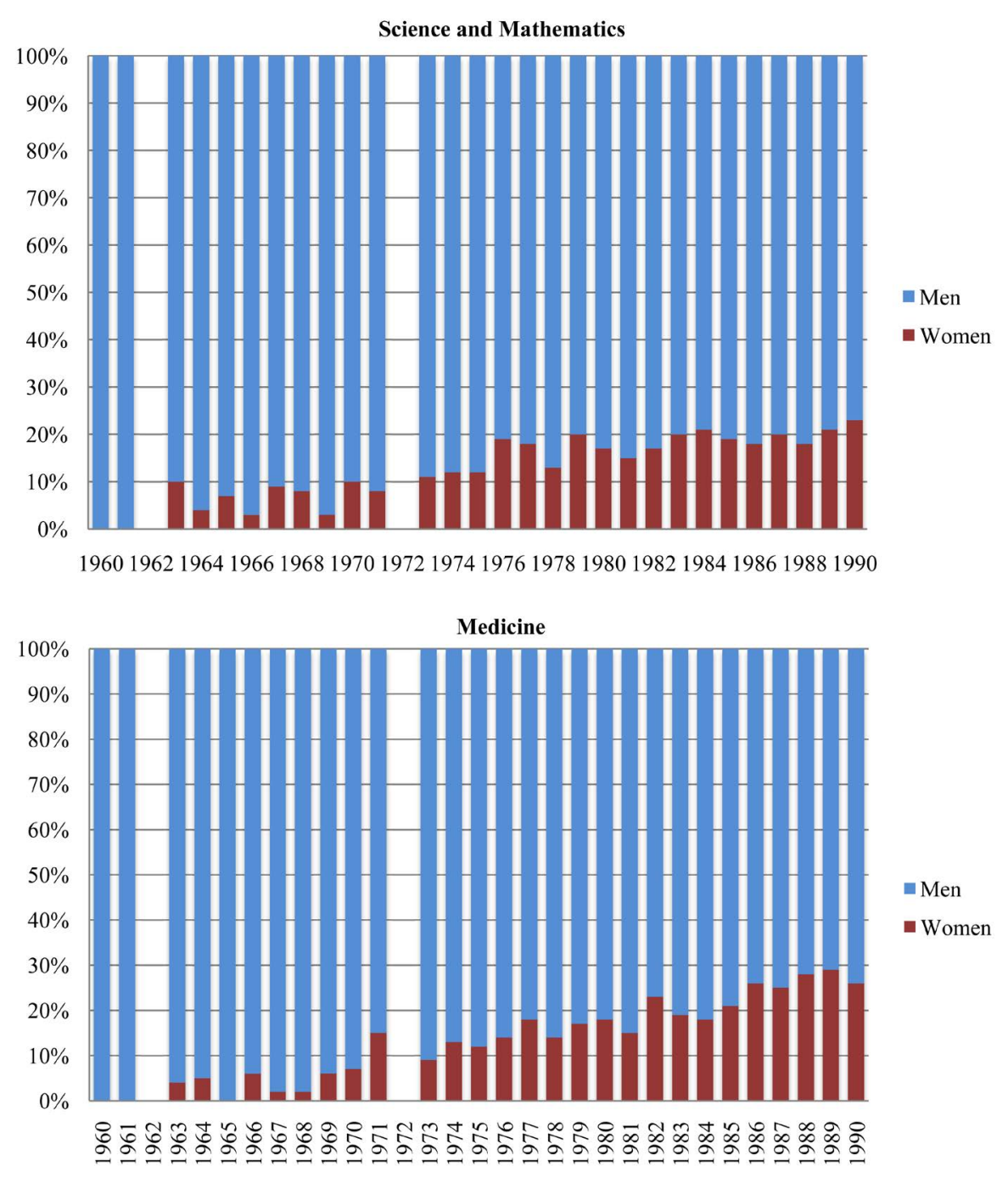

\section{B. Growth per disciplinary domain}

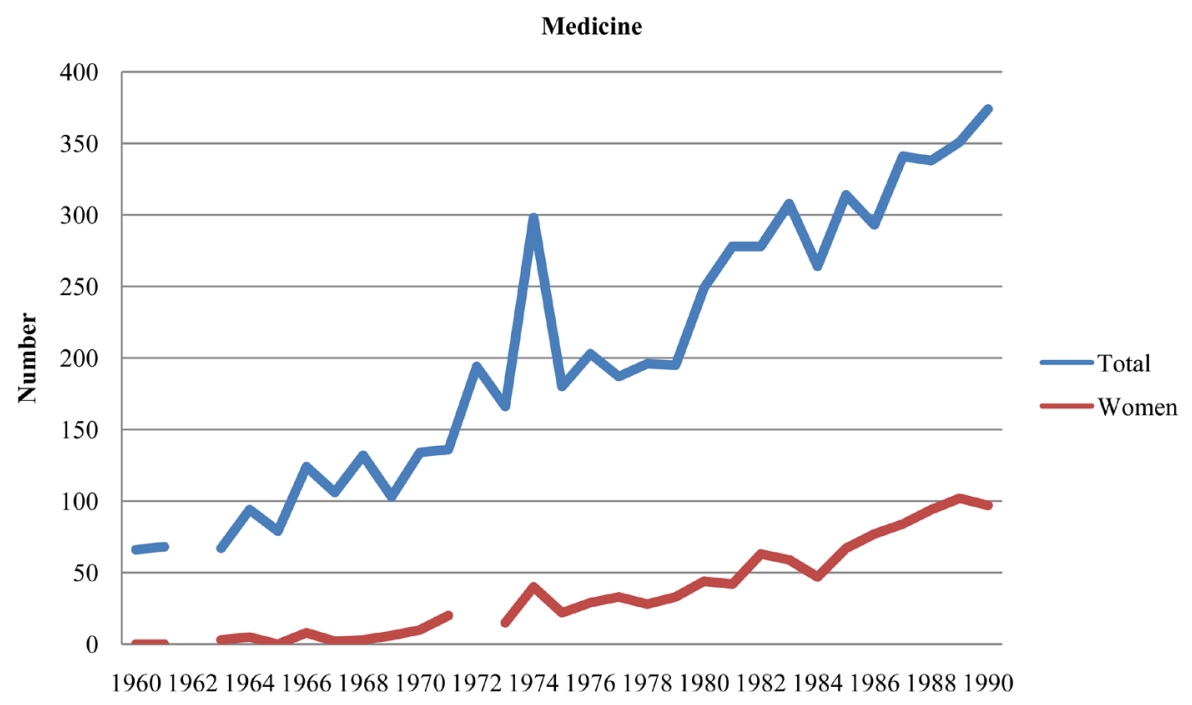




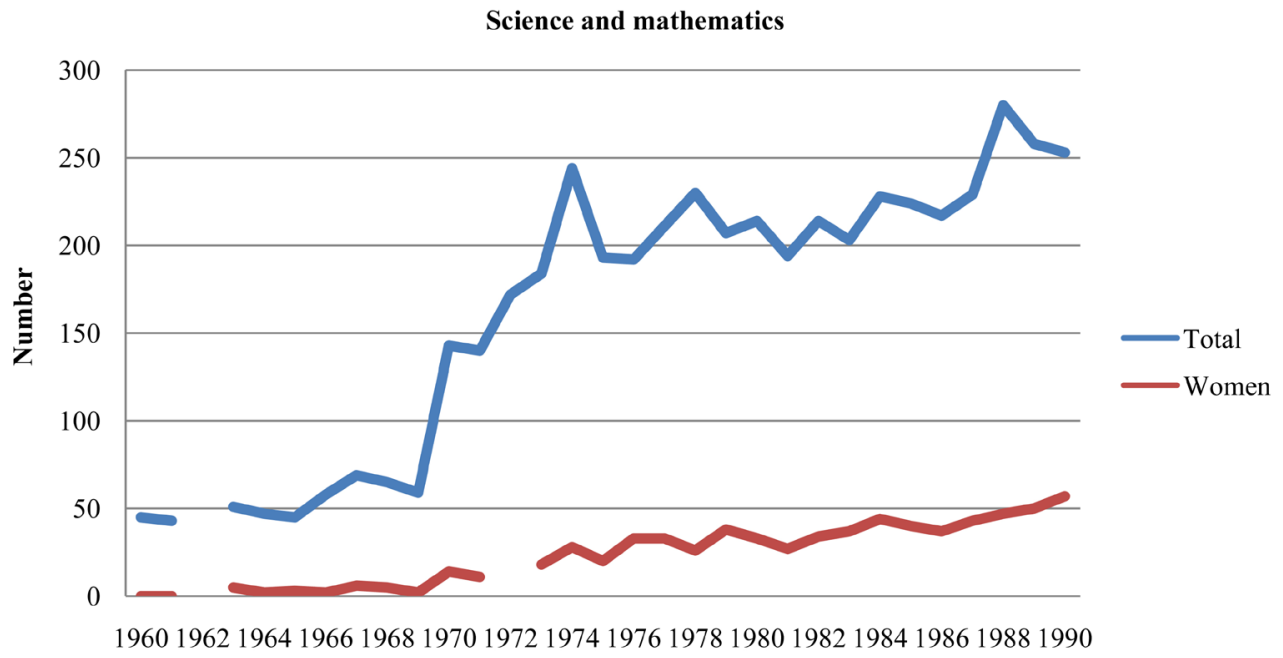

Technology

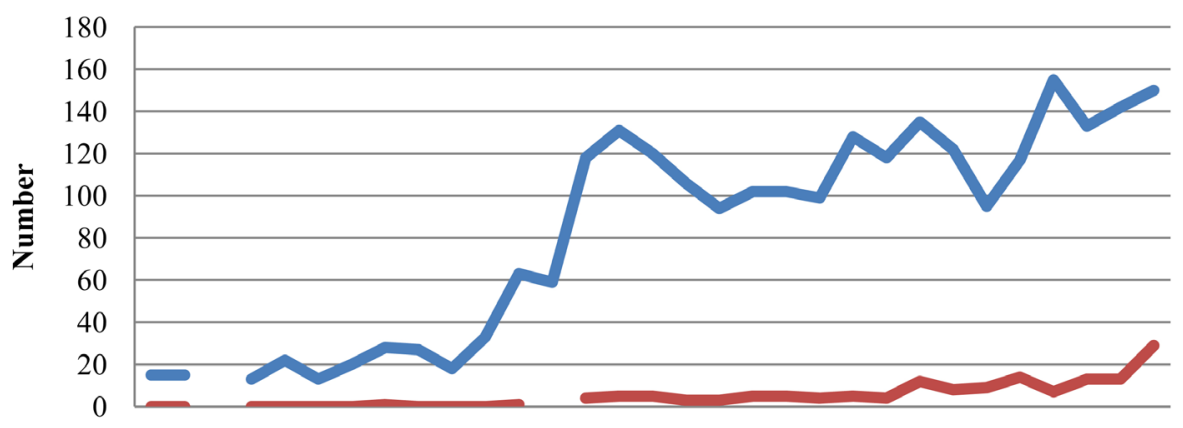

Total
Women

1960196219641966196819701972197419761978198019821984198619881990

Social Sciences and Economy

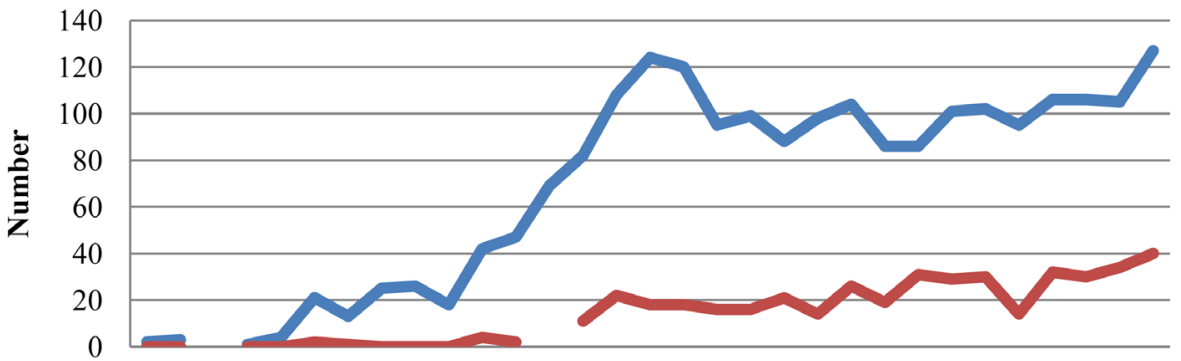

Total

Women

1960196219641966196819701972197419761978198019821984198619881990

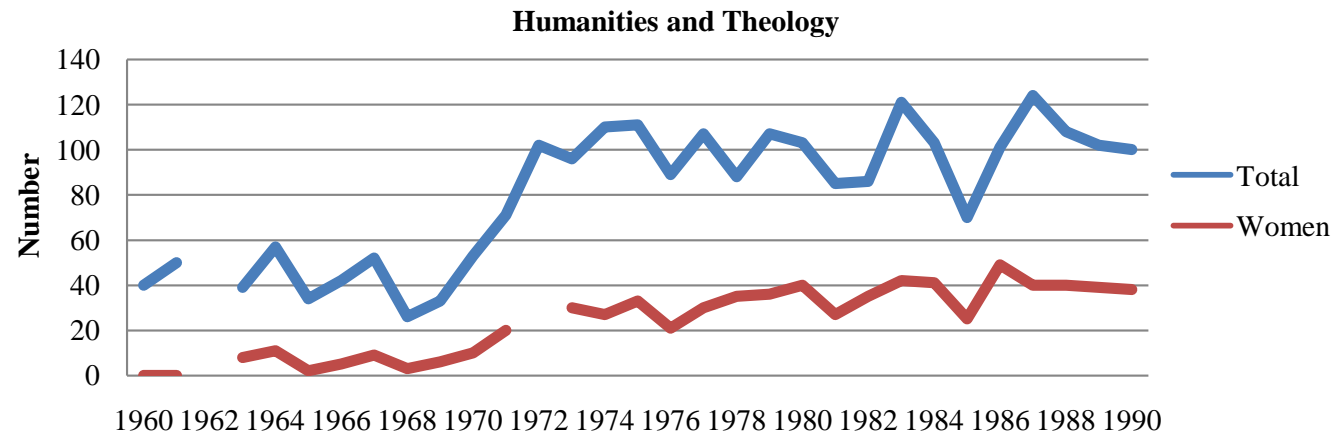




\section{Ph.D. frequency, 1960-1990. Growth in five smallest disciplinary fields (n)}

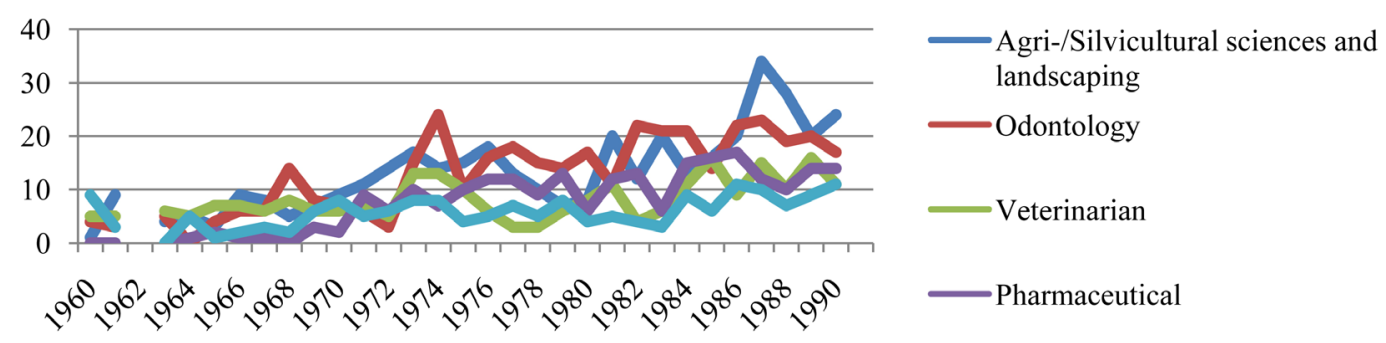

\section{Submit or recommend next manuscript to SCIRP and we will provide best service for you:}

Accepting pre-submission inquiries through Email, Facebook, LinkedIn, Twitter, etc. A wide selection of journals (inclusive of 9 subjects, more than 200 journals)

Providing 24-hour high-quality service

User-friendly online submission system

Fair and swift peer-review system

Efficient typesetting and proofreading procedure

Display of the result of downloads and visits, as well as the number of cited articles

Maximum dissemination of your research work

Submit your manuscript at: http://papersubmission.scirp.org/ 